\title{
An Openness to Experiment: Ruy Duarte de Carvalho's Anthropological Field Photography in Rural Southern Angola and its Archival Reusages
}

\author{
INÊS PONTE* \\ Institute of Social Sciences, University of Lisbon, Portugal \\ https://orcid.org/0000-0001-5612-5927
}

\begin{abstract}
This article explores the afterlives of the photographic production by Ruy Duarte de Carvalho (1941-2010), a Portuguese-born Angolan anthropologist who amidst the country's long-lasting civil war (1975-2002) engaged with the Ovakuvale transhumant shepherds dwelling in the semi-arid region of southern Angola. Through the 1990s, Carvalho used analogue photographic cameras to document his fieldwork among the Ovakuvale, and afterwards engaged in various experiments with the medium for ethnographic purposes. Departing from the current assemblage of Carvalho's personal archive that remains after he passed away, I explore distinct photographic relations connected to public usages of his Ovakuvale images during his lifetime, to discuss the ways in which he articulated them through diverse expressive modes and ventures - such as watercolours, illustrated publications, temporary exhibitions and a theatre play. Offering the opportunity to surrender to a broad experimental practice that makes his overall Ovakuvale ethnography particularly revealing, I project through the current archival assemblage a comparative approach to the rationales guiding the presentation of his Ovakuvale field images, to discuss salient temporal relationships between his method to produce and later reuse these images in postcolonial times.
\end{abstract}

\section{Introduction}

An increasing body of anthropological studies on archival photographs examines the work of Africanist ethnographers who developed a photographic practice in the field. Studies about collections and ethnographers linked to British colonial configurations such as Isaac Schapera (1905-2003), ${ }^{1}$ Edward Evan Evans-Pritchard (1902-73), ${ }^{2}$ Max

* This research was supported by the European Commission under a Marie Curie Individual Fellowship (747508), and by the Foundation for Technology and Science, Portugal, under Grant SFRH/BPD/115706/2016. I thank Patricia Hayes for the attentive feedback and support, as well as the feedback provided by the anonymous reviewers that helped in improving this article.

1 J.L. Comaroff, J. Comaroff and D. James (eds), Picturing a Colonial Past: The African Photographs of Isaac Schapera (Chicago: University of Chicago Press, 2007).

2 C. Morton, 'Double Alienation: Evans-Pritchard's Zande and Nuer Photographs in Comparative Perspective', in R. Vokes (ed), Photography in Africa: Ethnographic Perspectives (Woodbridge: James Currey, 2012), 33-55. 
Gluckman (1911-75) ${ }^{3}$ or Monica Hunter Wilson (1908-82) have shown how fertile such engagements can be with institutionalised anthropologists' personal archives in order to consider the role of photography in anthropology. With their diverse approaches to authored collections, such studies have nurtured the discussion of the medium's role for the discipline's evolving visual culture, offering valuable insights regarding the triangular relation between fieldwork, photography and ethnography occurring during the colonial era, a period of anthropology's academic consolidation and professionalisation.

Retracing archival photographs that were selectively and sporadically published in a dispersed way or that have remained unpublished, through approaches that reunite the backstage processes of participant observation or trace the development of ethnographic accounts, these studies provide a sense of revealing hidden dimensions of the role of photography for ethnography. Also analytically grounded in the relation between the archive and the former lives of its materials, I look at the role of the medium at a later stage in Africanist ethnography by exploring the production and later lifetime usages of field photography by Ruy Duarte de Carvalho (1941-2010), a Portuguese-born Angolan anthropologist who amidst the country's longstanding civil war (1975-2002) engaged with the Ovakuvale transhumant shepherds living in the semi-arid region of southern Angola. Carvalho's work carried out after Angola's independence from Portuguese colonialism sheds light on usages of visual documentation in the aftermath of a former colonial context with regard to what is nowadays considered a classical anthropological setting: the ethnographic research of an ethnically distinguishable people located in a peripherally governed territory.

Carvalho never separated his ethnographic practice regarding the Ovakuvale from a political stand - a marginal view on marginal subjects, for which he sought intellectual independence and structural autonomy. His work speaks broadly about matters that are often not easily captured visually - the interlinkages between the colonial past and the independent present in the lifeworld of marginal subjects in a recent nation-state in civil war, for which he scrutinised historical sources in relation to his ethnographic data. His work found inspiration in political literature on African pastoralists and he followed closely historians working on the Angolan context. ${ }^{5}$ His work is deeply concerned with the interconnections between the history of Angola more broadly and that of the pastoralist Ovakuvale, and is not easily matched by other Angolan research to date. Nonetheless, Carvalho kept experimenting with images that documented his annual fieldwork trips between 1992 and 1997 into the Ovakuvale region. His diverse lifetime interests and opportunities to use his

3 C. Wingfield, 'Photographing "the Bridge": Product and Process in the Analysis of a Social Situation in Non-Modern Zululand', in R. Vokes (ed), Photography in Africa: Ethnographic Perspectives (Woodbridge: James Currey, 2012), 56-80.

4 A. Bank, The Life, Work and Legacy of Monica Hunter Wilson (1908-1982), FHISER Research 9 (Fort Hare Institute of Social and Economic Research, 2008).

5 He was well versed in what are nowadays considered classical ethnographies, such as E. Evans-Pritchard, The Nuer (Oxford: Clarendon Press, 1940), and on more recent approaches to ethnicity in Africa, such as J.-L. Amselle and E. M'Bokolo, Au Coeur de l'ethnie: Ethnies, Tribalisme et État en Afrique (Paris: Découverte, 1985) and I. Kopytoff, The African Frontier (Bloomington: Indiana University Press, 1987). On the Angolan context, I highlight the work of political sociologist Christine Messiant, rural sociologists Fernando Pacheco and Franz Heimer, and historians David Birmingham, Isabel Castro Henriques, Gervase Clarence-Smith, Jill Dias, Joseph Miller, Maria Conceição Neto and René Pélissier. 
Ovakuvale field photography in the post-independence context warrant a better understanding of the circumstances of his documentation field method.

I build this discussion on a set of archival tasks I began to carry out regarding Carvalho's private archive five years after his death. I attended to a request by his family to produce a preliminary inventory to help them decide its destiny. As a younger scholar, the chance to access the resources of an anthropologist who had developed substantial and extensive fieldwork and historical research in the region in which I had also specialised was a thrilling opportunity. ${ }^{6}$ My familiarity with Carvalho's oeuvre was helpful to map the massive assemblage of materials his multidisciplinary work had generated throughout his multifaceted career. Later, beyond my own particular research interests, I decided to prioritise making his work publicly available in the short term instead, collaborating in the curatorship of $A$ Delicate Zone of Commitment (ADZoC), ${ }^{7}$ and developing RDC Virtual, an online film repository associated with a catalogue, ${ }^{8}$ which hosts some of the films Carvalho had directed in his youth that had become difficult to access. Adding to that, I gave support to depositing his archive with a Portuguese philanthropic institution that has a digital archival platform, which currently provides online access to a range of graphical works and registers Carvalho produced in his lifetime. ${ }^{9}$

This article draws on my experience as an archivist with an overall understanding of Carvalho's existing materials, complemented with a closer look at the ramifications of his photographic practice. Carvalho was quite methodical, producing several devices to keep track of both his Ovakuvale field data and bibliographical resources consulted in various sites - including France, Namibia, Portugal and South Africa at different moments of his life. ${ }^{10}$ Persistently going back and forth from handwritten to typewritten, from analogue to digital formats, Carvalho not only used much of the data he had generated in various formats but also often reused large parts of it for further projects. Such working processes make retrieving his progressive accumulation of either field or secondary data a complicated task. A personal archive is ruled by the principles defined by its maker, and I do not consider myself to have fully apprehended Carvalho's logic. As it offers a framework for looking back and forth, and, importantly, across different lifetime projects where images were activated, I rather prefer to consider the 'impurity of time'11 as a revealing concept to engage with the existing archived materials and the multiplicity of lifetime initiatives surrounding his Ovakuvale ethnographic work to discuss some of the lives of his field images.

6 I. Ponte, 'Crafted "Children”: An Ethnography of Making and Collecting Dolls in Southwest Angola' (Unpublished PhD thesis, University of Manchester, 2015).

7 A.B. Oliveira, I. Ponte and M. Lança, A Delicate Zone of Commitment, Exhibition, 2015, http://www.buala.org/pt/galeria/ uma-delicada-zona-de-compromisso; see I. Ponte, 'Conhecer e Animar o Arquivo de RDC: Resultados de Um Processo de Inventariação', in Diálogos Com Ruy Duarte de Carvalho (Lisboa: Buala and CEC-FLULisboa, 2019).

8 E. Carvalho, L. Carvalho and I. Ponte, 'RDC Virtual', Digital Film Archive, 2016, www.vimeo.com/rdcvirtual; I. Ponte, 'RDC Virtual Catalogue', Film Catalogue, 2020, https://osf.io/r8xjg/.

9 'Ruy Duarte de Carvalho', Casa Comum, 2017, http://casacomum.org/cc/arquivos?set=e_11121.

10 With respect to intellectual nurturing of his research on the ovakuvale, Carvalho mentions dialogues with researchers concerned with Southern Africa at the Parisian École des Hautes Études en Sciences Sociales, and related research centre in Bordeaux, and also researchers at the University of Cologne, interested in the Ovaherero from Namibia and Botswana. See, among others, Os Kuvales na História, nas Guerras e nas Crises: Artigos e Comunicações, 1994-2001 (Luanda: Editorial Nzila, 2002), 151.

11 G. Didi-Huberman, The Surviving Image: Phantoms of Time and Time of Phantoms: Aby Warburg's History of Art (University Park, PA: Pennsylvania State University Press, 2017). 
I propose to discuss here Carvalho's Ovakuvale field photographic production, locating the ways the author produced them and later activated them in particular contexts and for specific ethnographic purposes. Here the content and use of the photographs are inextricably linked, creating in some cases 'photographic complexes $^{\prime 12}$ - where certain images from a larger repertoire have occasionally participated in and devolved into other 'things'. Following photographs as 'social objects', ${ }^{13}$ I articulate Carvalho's use of photography as a documentation practice with his later other active engagements with the field photographs in a variety of formats. Interweaving backwards from the archive to the field, I discuss intermingled sets of in-between creative productions such as drawing and water colouring, illustrated publications, temporary exhibitions and a theatre play. I thus juxtapose hidden features of archival materials with varying kinds of shorter and longer public lives.

As recovered through the assembled materials that represent a 'crippled' version of Carvalho's personal archive, and mediated by a diversity of archival and curatorial approaches, Carvalho's willingness to embark on varying ventures to use the Ovakuvale field images he made in the 1990s opens a discussion on the range of creative uses of field images in anthropology. I construct a meandering move between the residues of his personal archive and various exercises developed in different moments of his life to reveal the processes through which Carvalho kept transforming his visual documentation into a particular imagery for his larger project of Ovakuvale ethnography. For Carvalho photographs were able to evoke the Ovakuvale lifeworld in ways that would not have occurred had they remained in his archive; thus exploring his fieldwork experience highlights the evolving thinking guiding their succeeding usages. Whether by engaging with them through a set of personal strategies, or by collaborating in several initiatives to disseminate his work that also determined their activation, Carvalho's ethnographic signature regarding photography resides in incessantly thinking about his field images.

Finally, I aim to keep the Ovakuvale shepherds in sight, the people whom his ethnographic work is about, to be faithful to Carvalho's intentions. To highlight relevant features related to his 1990s Ovakuvale photographic production, I start by outlining Carvalho's biography.

\section{Carvalho's Biography as Context for His 1990s Ovakuvale Photographic Production}

Just before the Angolan civil war (1975-2002), Carvalho, until then an agronomist by training and a poet by choice, began to be a filmmaker. It was his brief filmmaking career in recently independent Angola that led him to become an anthropologist, and later a teacher and multifaceted writer. ${ }^{14}$ In mid January 1992, in his academic break

12 E. Edwards, 'Objects of Affect: Photography Beyond the Image', Annual Review of Anthropology 41, $2012,223$.

13 D. Zeitlyn, 'Anthropology in and of the Archives: Possible Futures and Contingent Pasts. Archives as Anthropological Surrogates', Annual Review of Anthropology 41, 1, 2012, 465.

14 For a detailed biography, see L. Apa, 'Ruy Duarte de Carvalho', in E.K. Akyeampong and H.L. Gates (eds), Dictionary of African Biography (Oxford: Oxford University Press, 2012), 36-8. 
as a university teacher in Luanda, the country's capital, Carvalho started to conduct fieldwork in southern Angola. The episodic South African military invasions taking place over more than a decade, particularly in the southern region, had stopped. Yet the broader diplomatic resolution reached in the Bicesse Accords (May 1991) for the already lengthy civil war between the ruling Movimento Popular de Libertação de Angola (MPLA) and its opponent União Nacional para a Independência Total de Angola (UNITA), had begun to show cracks. ${ }^{15}$ Carvalho's timing for the beginning of his new ethnographic venture resulted in him being present in situations of local unrest among previously armed shepherds who strongly sided with the MPLA. In the following five years, Carvalho kept conducting annual field missions, tenaciously developing an ethnographic project on the Ovakuvale during the academic breaks in his post as an anthropology teacher at the Architecture Department of the Agostinho Neto University.

His Ovakuvale project was a major change of focus after his training in anthropology, in which he had conducted research on Luanda fishermen. Emerging after having lived through the civil war in the capital for more than a decade, it implied generating a new field and one quite far away from where he was living. However, as the son of a Portuguese settler, Carvalho already had an affinity with the region from his childhood in Moçamedes since the late 1940s. Having attempted a settler's life in his younger years as an agronomist after training in his city of birth, Santarém, he left Angola before its independence and took a cinema course in the UK. Returning soon before independence and during his brief career as a state-sponsored filmmaker, he directed several documentaries as well as the only Angolan feature film spoken in a vernacular language, with agropastoralist Ovanyaneka people in the southern region. His films were shot in different parts of the country, but the set which related to the rural southern context sparked his interest in anthropology. The country's constraints in the early 1980s, however, led to his choice to research Luanda's fishermen for his $\mathrm{PhD}$ at a French university, the École des Hautes Études en Sciences Sociales in Paris. ${ }^{16}$

Carvalho's 1990s ethnographic field research then focused on the Ovakuvale, known as transhumant shepherds who circulate within a vast semi-arid territory. In a country so centred around Luanda, Carvalho appears to have recovered his belief that to engage with peripheral populations could testify to the issues at play in a recent nation-state that had a turbulent colonial past and was living an equally turbulent independent present. ${ }^{17}$ His childhood acquaintances appeared as a conduit

15 The Bicesse Accords established the first presidential elections after independence, scheduling them to take place in late September 1992. For further details, see D. Birmingham, 'Angola', in P. Chabal (ed), A History of Postcolonial Lusophone Africa (Bloomington: Indiana University Press, 2002), 137-84.

16 Carvalho obtained access to the doctoral programme after a diploma dissertation addressing cinema in Africa through his feature-length fiction film Nelisita, B\&W, 16 mm (Instituto de Cinema Angolano, 1982), www.vimeo.com/154832740, arguing there for anthropology's other roles in cinema, beyond ethnographic films. Sociologist Jean Copans supervised Carvalho's academic dissertations and thesis; the examiners of the former were historian Marc Ferro and Africanist anthropologist JeanLoup Amselle.

17 The documentary 'Uma Festa para Viver' (R. Carvalho 1975. Televisão Popular de Angola, available online: vimeo. com/157407906) registers the countdown during the 15 days leading to Angola's independence from the point of view of a suburban neighbourhood in Luanda. His book Como se o Mundo não tivesse Leste (Luanda/Porto: União dos Escritores Angolanos/Limiar, 1977) gathers three fictional short stories on African lived experiences in rural contexts during late colonial times. 
into the rural universe he proposed to understand better, giving him the advantage of getting to know the point of view of a borderline population in the Luanda-centric country. In addition, by shifting his attention from urban to rural contexts, he drew a kind of inverse itinerary within anthropology's increasing concerns with urban contexts. He had managed to purchase a jeep as a payoff from consultancy work in central Angola, and local connections in Namibe city (formerly and subsequently Moçamedes) provided him with financial resources and a research assistant to enable him to spend several months each year in the hinterlands of the same province, which his meagre teaching salary at the time did not. Carvalho's biography and the history of Angola appear deeply intertwined in his work - aspects he explicitly deals with in all his books, regardless of genre. In his later literary work, Carvalho always looked to locate the peripheral identities of the subjects he wrote about along with that of himself as the writer, after thinking - literally - of his life trajectory as made of curves and counter-curves - to apprehend its lack of linearity (Figure 1). ${ }^{18}$

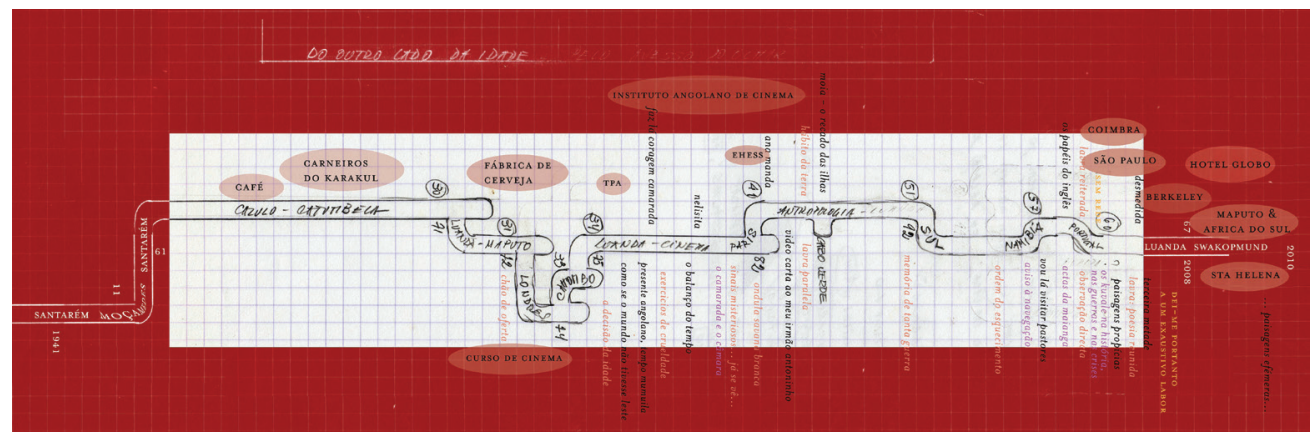

Figure 1: Based on Carvalho's outline of his life trajectory on a notebook, refashioned for display at the posthumous exhibition $\mathrm{ADZoC}, 2015$. Coloured typewritten text locates films, books and exhibitions; filled circles locate unmarked life experiences and travels.

The multitude of Carvalho's earlier life experiences converges also in a great number of experiments - he explored an anthropology of interconnections not only through various expressive fields including film, painting and literature, but also styles. Carvalho has described his writing style as evolving into a 'kind of fiction, or half fiction', a 'certain fiction' that he created only after having lived through many different experiences, finding his initial endeavours in poetry and filmmaking, and later anthropology, particularly inspiring. ${ }^{19} \mathrm{~A}$ few anthropologists have used the term 'kaleidoscopic' to define many of the crossovers found in the work he has developed throughout his career. ${ }^{20}$ Though Carvalho did not use the term for self-description,

19 'Falas \& Vozes, Fronteiras \& Paisagens... - Escritas, Literaturas e Entendimentos', Sete Palcos, $2006,10$.

20 J.F. Dias, 'Dei-Me Portanto a Um Exaustivo Labor', in J.F. Dias (ed), Exhibition Journal of Ciclo Ruy Duarte de Carvalho: Dei-Me Portanto a Um Exaustivo Labor (Lisbon: CCB, 2008), 3, and, in the same publication, M.V. Almeida, 'Antropologia e Literatura: a propósito e por causa de Ruy Duarte de Carvalho', 12-13. See also J. Lucas, 'Ruy Duarte de Carvalho: pela miscigenação das artes', Arte Capital, 2 February 2008, http://www.artecapital.net/opiniao-61-joana-lucas-ruy-duarte-decarvalho-pela-miscigenacao-das-artes. 
it catches the ways in which he creatively refashioned his data into various expressive forms, offering a valuable orientation to his thinking and work. I hope to demonstrate how it also intimately connects with the open-minded way Carvalho engaged during his lifetime with his Ovakuvale images, made initially to document his fieldwork. While the difficult economic circumstances of the 1990s in Angola are relevant to situate the historical conditions of his fieldwork - only possible by seeking informal support - Carvalho's reuse of his images departs from his understanding of them as mediating his experience of the Ovakuvale universe, while attending to his other professional occupations.

\section{Carvalho's Archive and His Experiments with Field Photography}

In its current state, Carvalho's personal archive provides glimpses into his working methods, in a way that is somewhat backwards. The assemblage of materials I call his personal archive embodies unequal traces of past events and of their successive uses that partially rearranged previous archived materials. It is noticeable that Carvalho worked in response to changing inputs and needs, reshuffling many of the materials according to the project at hand. Carvalho's archive resonates with how personal archives may have a lively dynamic life. ${ }^{21}$ Carvalho's sudden death meant that it is the remains of a once extremely lively archive and, as a result, its current assemblage is now a temporally messy one. ${ }^{22}$ The ways in which Carvalho's archival materials are fragmented between analogic, print and digital, and have been involved in different kinds of processes and activities, prevents an attempt to approach it in a temporally linear way. I find it more profitable to look at this archive as providing an intermediate and partial access not only to Carvalho's experience of the field but also to his field photography methods or to later diverse usages, some of them public.

Carvalho's archive materials reveal the last 'afterlife' of his field images more strongly than their original conditions of production or previous other lives. For instance, most of the set of prints of his Ovakuvale field photographs are packed in a series of envelopes related to the second exhibition in which he was involved (2008, Dei-me Portanto a um Exaustivo Labor/So I Carried Out an Exhaustive Labour), which addressed his overall work related to Angola as an already accomplished multifaceted writer. Existing preproduction documents, related to a previous experiment, do not consist of commonly printed copies - but rather on the intermediate selection of field images for his book Vou Lá Visitar Pastores/I'm Going There to Visit the Shepherds, ${ }^{23}$ the first time he used his field photography for public purposes. This book repre-

21 H. Behrend, "Celebrating Life": The Construction of Photographic Biographies in Funeral Rites among Kenyan Christians', in C. Morton and D. Newbury (eds), The African Photographic Archive: Research and Curatorial Strategies (London: Bloomsbury, 2015), 77-94.

22 The current archive is in Lisbon, and results not only from a progressive gathering and use but also from occasional selective processes linked to Carvalho's change of residence - retiring from his university teaching after more than three decades in the same house in Luanda, he settled in Swakopmund, Namibia, in 2008.

23 Vou Lá Visitar Pastores: Exploração Epistolar de Um Percurso Angolano Em Território Kuvale (1992-1997) (Lisbon: Cotovia, 1999). I reference the original version, by Cotovia, a small independent Portuguese publishing house. In the following year a Brazilian edition was published by Gryphus and another Portuguese edition by Circulo de Leitores. In 2015, Cotovia released a pocket edition. 
sents a significant turn in Carvalho's literary work, where he experiments with a new hybrid style distinct from his former ethnographic writing on the Ovakuvale. ${ }^{24}$ Vou Lá is responsible for several later opportunities that emerged to collaborate in formal experiments with his work - occasions where his field photographs were diversely activated. More difficult to date is another agenda Carvalho developed regarding his Ovakuvale field images, using them as inspiration for drawings and watercolours.

Considering Carvalho's other experiments with his Ovakuvale field photography, they appear to have as many material presences as absences. For instance, the existing materials in the archive related to the 2006 exhibition Sem Rede/Without Net do not testify to the role printed field photographs played in it. This brings an awareness of some usages in Carvalho's lifetime not leaving traces in the remains of his personal archive. It also highlights the relevance of analytically combining the broader spectrum of traces generated since his Ovakuvale fieldwork, not letting either the field, the archive or the public occurrences dominate the others, but rather looking at the relationships they establish - for instance, how both a 2006 issue of a magazine dedicated to his work and the 2008 exhibition journal are illustrated with varying combinations of the visual artefacts Carvalho created: field images, drawings and watercolours. Another event where the Ovakuvale images were activated is a theatre play, with its ephemeral presentations alluded to in the promotional materials. All these experiments appear unequally represented in his personal archive, yet looking for their traces in the public sphere and relating them to the archival materials available, shaped a tentative map of Carvalho's field production, and also framed some orientations in his thinking in later usages (Figure 2).

Variably dispersed on negatives, contact sheets and prints that often have incomplete information about their production, the existing analogic photographs made over his 1990s annual expeditions into the southern region gain a different dimension when cross-referenced either with his published work or his field diaries. The latter consist of a complex handwritten system later transcribed to the computer and a digitally born diary, usually not written on the same day in the field, but soon afterwards. The next section looks into those field materials, the diaries and photography practice.

\section{Setting up Carvalho's Ovakuvale Field Photography: Now the Archive, then the Field}

The Ovakuvale photographic materials existing currently in Carvalho's archive include about 46 rolls in $35 \mathrm{~mm}$, both colour and B\&W, a few contact sheets, two of them missing the negatives, clustered sets of colour prints and dispersed B\&W and

24 R.D. Carvalho, 'O futuro já começou? Transições políticas e afirmação identitária entre os pastores kuvale (herero) do sudoeste de Angola', Lusotopie, 2, 1, 1995, 221-37; 'Paix et Guerre Chez Les Pasteurs Kuvale Lettre de Vitivi', Politique Africaine, 57, 1995, 85-93; Aviso à Navegação: olhar sucinto e preliminar sobre os pastores Kuvale da Província do Namibe com um relance sobre as outras sociedades agropastoris do sudoeste de Angola (Luanda: INALD, 1997). Except for the compilation of published articles and oral presentations in Os Kuvales Na História, Nas Guerras e Nas Crises (2002), from Vou Lá onwards, Carvalho's writing developed a unique fictional writing style, often accompanied with a few line drawings. 


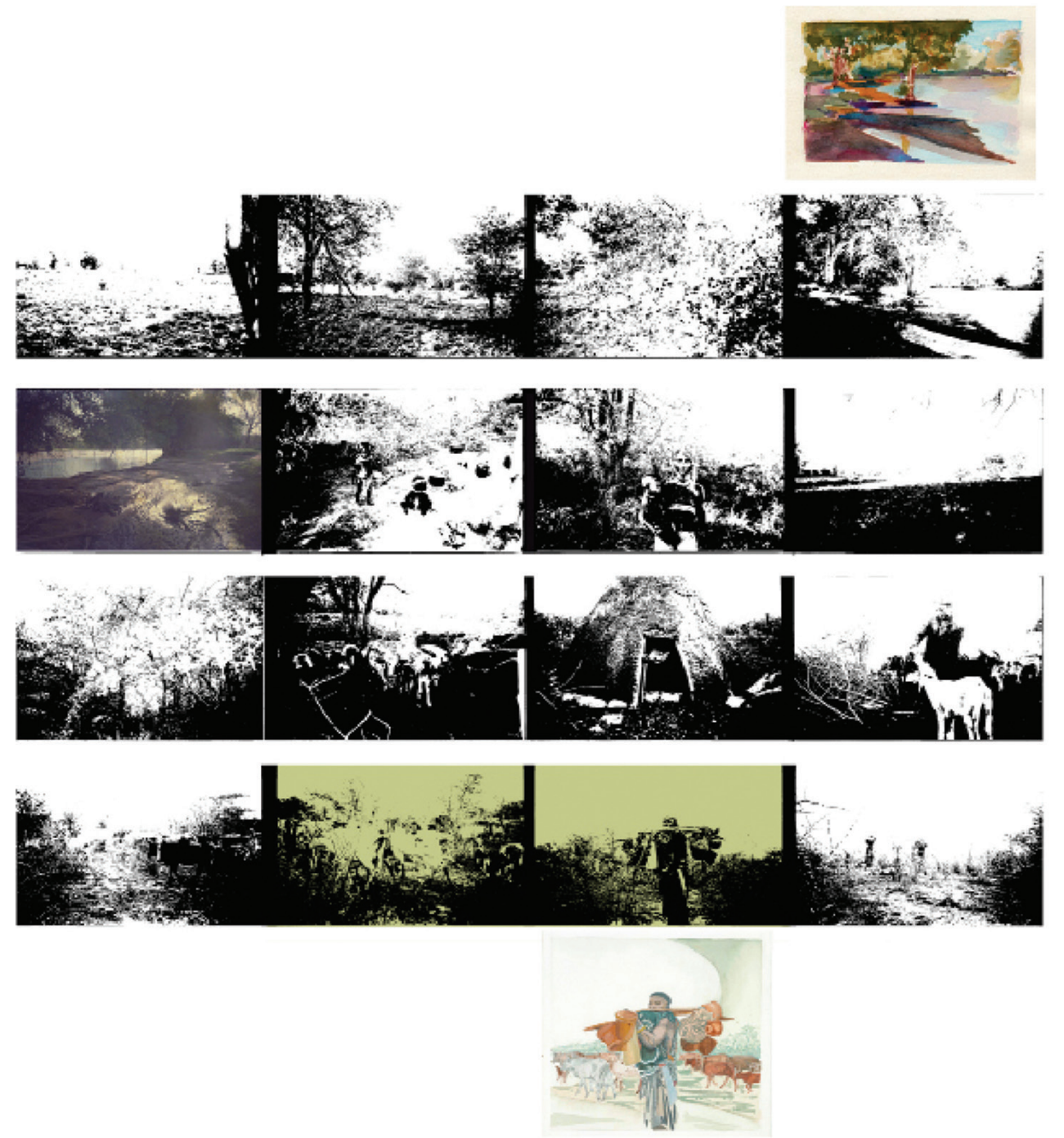

Figure 2: Contorted sampling. The juxtaposition of Carvalho's field production with later usages. The last 16 frames of R7w/1993: white filter signals archived negative; intermediate proofs from 1999 are signalled with a green filter. The images in Vou Lá had a white filter; yet I use yellow and green, the book's cover colours, to signal published and intermediate repertoire. An image displayed in the 2008 exhibition (top second from the left) appears unfiltered. The drawings are undated.

colour prints. The fewer B\&W films (a ratio of 5 in 46) indicate a second camera in the earlier expeditions. It is possible to generically date most of these materials from his annual fieldwork trips between 1992 and 1997, and four of them to 2006, during a visit to Namibia. Near the end of his second trip, Carvalho mentions in passing in his fieldnotes problems with one camera battery and then resorting to the other camera. I tend to associate many rolls with the use of a compact camera. The number of annual trips comprising Carvalho's long-term fieldwork, combined with the somewhat disorderly storing of the analogic materials, complicated matters for a precise genealogy 
of some of them. Thus my tentative ordering of the rolls involved ascertaining their production years by working through approximation. Dates electronically inscribed on a few rolls provide a good example of how clues related to temporal accuracy can be deceptive, and thus some of the challenges I faced in my circumscribed aim.

Carvalho's typewritten diaries provide an overview of his fieldwork periods for all the years, and make the dates digitally inscribed on two or three rolls intriguing: there is a mismatch between his field diary and digitally inscribed dates for 1993 and 1994. As the package of a related roll shows, it was developed in 1992, pointing to an unsuccessful manual date change made by the photographer while the film was in use. Importantly, this raised my awareness of the caution necessary in looking for temporal precision regarding these images, and of the benefits of cross-referencing information from various sources.

Carvalho created a multitude of resources, many of them with temporal clues, such as manual calendars to track several of his field trips. They were systems to guide him and thus do not facilitate an outsider's easy understanding of the materials resulting from each expedition. In his Ovakuvale field diaries, Carvalho explicitly mentions photographing a few events that the images portray. ${ }^{25}$ If revealing details such as an exceptional field companion or other unique occurrences help to establish the trip's year for some rolls, as Carvalho often returned to visit the same locations in different years, and in some attended or photographed the same kind of events - for instance, divination using a sheep's entrails, or ritualised slaughter and meat consumption - it is not straightforward to use his fieldnotes to locate precise dates for others. Carvalho occasionally also mentions in passing issues related to framing, showing some calculated practice, although my perception of this was not immediate.

A reading of Carvalho's field diaries about the expeditions generates an overall picture of frequent highly mobile visits over the years motivated by many variables from personal relations to the particular conditions of his jeep, health, provisions, or scheduled plans. As Carvalho often wrote his fieldnotes after some days, it is no simple task to keep track of events that happened in various temporary camping spots or nearby places. Unnecessary for him to describe them to himself, an external reader of his diaries constantly stumbles on the tenuous geographical and temporal coordinates of his fieldwork. Targeted to an audience, Angolan or otherwise, to whom the Ovakuvale and their territory would be strangers, Carvalho made that familiarisation effort in the book Vou Lá Visitar Pastores instead. The diaries offer more general sensations promoted by the relatively frequent reappearance of certain topics related to the colossal demands of fieldwork among people engaged in a highly mobile lifestyle in a vast semi-arid territory, along with Carvalho's perception of the slow progress of his inquiry, as well as setbacks of several sorts. Besides the amount of space taken up in the diaries by mechanical problems with his jeep on most if not all of the expeditions, alongside the frequent disruptions caused by his Ovakuvale companions' alcohol consumption, Carvalho, already in his fifties, often wrote about the effects of

25 Carvalho also mentions filming on some occasions but available archived footage relates only to his previous filmmaking experience from 1975-86. 
ageing. His writing shows the perseverance needed to conduct fieldwork, particularly in the initial years when major adjustments were required. This contrasts with the more serene tone in his fieldnotes in later missions, showing he had found his own strategies to carry on his work.

Christopher Morton has studied the shifting features of Evans-Pritchard as an ethnographer-photographer according to the social relationships he established in his fieldwork among the Azande and the Nuer in the 1920s and 1930s. ${ }^{26}$ Morton argues for a more relational understanding at two levels: attention to the indigenous agency of the people photographed, and a broader situational understanding created from the spatial and temporal relationships of one image with others. The tentative order engendered by the juxtaposition of archival material clues, Carvalho's field diaries and mapped traces of his later usages, generates an account about his photography production that establishes a gradual change in his use of the camera as documentation over the five annual trips to the Ovakuvale territory, from one trip to another.

From the initial euphoria of encountering childhood companions in his first field trip, illustrated in three frames he shares in their company, follows a trip during the rainy season, part of it spent camping near the temporary cowshed of one of his favourite contacts (see Figures 2 and 6). The rolls of the two first trips combine topics that Carvalho felt immediately important to document - such as milking, cattle in their everyday lives, close-ups of blossoming flowers - as well as random shots, the result of an uncontrolled camera or one aimed at the landscape while on the move. Carvalho created a particular alphabetical notation for 16 rolls belonging to the same production year, 1994. On that trip, the one which reunites the greater number of rolls, he used the camera mostly to document events such as makumukas, the women's spirit possession that ends in meat consumption, divination ceremonies and other sorts of social gatherings surrounding cattle slaughtering and meat consumption (see Figure 3). In the later field trips, Carvalho appears to have used the camera more sporadically, often taking photographs of unexpected events, such as the double burial at which he found himself in 1996, where he was enthusiastic to have photographed a shepherd carrying a Kalashnikov rifle distributed by MPLA. ${ }^{27}$

From time to time, Carvalho outlines in his field diaries his plan to collect data during a certain expedition, and some of his notes contain embryos of his later published writing. For instance, in the first trips Carvalho appears to struggle to find any sense in pursuing his ethnographic enquiry during the country's civil war, often expressing doubts about the work he intended to carry out. He appropriated many of these initial reflections in Vou Lá. Fieldnotes from later expeditions also show publishing plans, indicating how Carvalho used fieldwork for earlier stages of his writing. For example, his tentative first plan for Vou Lá Visitar Pastores, the book that melted together the varying experiences of visiting shepherds for years in a row, was made during one of the later field trips. 
In contrast with the blurred spatial boundaries of writing that developed between the field and other locations, compelled by the delay in accessing the results of his camera use, photographs appear very loosely in this process - they play a role both after fieldwork and far away from the field. Only in the city could Carvalho access developing shops that would let him see the resulting photographs. His archive also conveys evidence of photo development in France, after his 1994 trip. In Carvalho's later usage of the field images for what became his illustrated monograph, this temporal and spatial lag highlights the relevance of distance from the field, when his 'rumination' of both the field experience and historical research had stabilised into a written version. I discuss this process in more detail below.

\section{Glimpses at a Repertoire:}

\section{Carvalho's Initial Publication of His Field Photographs}

During his annual fieldwork with Ovakuvale pastoralist communities over the 1990s, distributed over 42 rolls, Carvalho made more than 1000 pictures. At the end of the decade, he published one of his most intriguing ethnographic books, Vou Lá Visitar Pastores, which is illustrated with some of his field images. The original edition has about 370 pages, with 55 images and an exquisite aerial sketch mapping the region addressed. Its subtitle situates both the kind of book the reader might expect and the temporal period in which it was created: 'An epistolary exploration of an Angolan journey through Kuvale territory (1992-1997).

In relation to anthropology's conventional academic standards, Carvalho's Vou Lá has two major experimental features. On the one hand, his writing engages creatively with some of the consequences of the 1980 s crisis of representation, ${ }^{28}$ discarding some of the discipline's classical academic conventions for a more open literary form. The text results from a multitude of sources, combining extensive contemporary fieldwork with archival research and historical ethnographical readings through a device that crosses fiction with realism: it flows as tape-recorded messages to a friend who had missed the narrator's journey into the region to meet the transhumant shepherds who inhabit it. Creatively compressing several field trips and research methods, the field images included in the book are graphically treated, another uncommon device by anthropological disciplinary standards. In Vou Lá the images were submitted to high contrasts and printed with neither colour nor grey scale. By avoiding printing more than a single tone, the transformation appears a creative way to overcome publishing limitations, with their presentation effecting a radically different aesthetics from both the usual ethnographic and humanist photography on African rural subjects in which realism was a major dimension..$^{29}$

J. Clifford and G. Marcus, Writing Culture: The Poetics and Politics of Ethnography (Berkeley: University of California Press, 1986).

Lacking a surrealistic bent, the device still has some affinities with a few of Carvalho's earlier ink drawings (such as $\mathrm{R}$.

Carvalho, 1978, As portas do Kalahari, http://casacomum.org/cc/visualizador?pasta=11183.001.001, or Um Jaga atravessou a Nação, http://casacomum.org/cc/visualizador?pasta=11180.017.001) published in a poetry book, Sinais Misteriosos... Já se Vê... (Lisboa: Edições 70, 1979), while making his major documentary oeuvre on the agropastoralist Ovanyneka, 'Presente Angolano, Tempo Mumuila' [Contemporary Angola, Time of the Mumuilas], 10 episodes, B\&W and colour, 16 mm, (TPA, 1979), https:// vimeo.com/channels/presenteangolano. 
Earlier I introduced the way Carvalho started to outline this book while in the field. The published version combined with the existing preproduction materials, consisting of 37 faxed pages dated from early April 1999 and a two-page plan, hint at a radically different process regarding its illustrations. His experiment with the images appears to have begun not only after he had accomplished a final manuscript but also occurring quite close to the publisher's release, early May 1999. The intermediate annotated proofs - as I started to call them since the pages have crop marks - show a broader preliminary selection made from the overall photographic material. Carvalho's related plan shows that this set of about 109 images is a sort of repertoire made with the manuscript in mind, thematic subsets gathering different numbers of images. The plan also highlights a second phase for his choice of which image to best portray his writing on a certain theme, revealing the role of the finalised manuscript as decisive for the final choice. The published book shows a third phase, a further screening process where some images were dropped, making visible how the apparently quick illustration process was quite a complex one.

Carvalho's notations on the intermediate highly contrasted image proofs and on the outline plan show his decision to incorporate images thematically in the text. Thus, when Carvalho writes about cemeteries, an image of a cemetery appears (see Figure 5); on the page in which he describes the desert flora and writes about a specific plant - providing also its scientific name - a field image of such a plant is displayed. Similar to Chris Wingfield's ${ }^{30}$ understanding of Max Gluckman's choice to publish a few reordered images regarding the inauguration of the bridge in his famous text proposing a processual approach to the event, Carvalho's purpose appears to have not been constrained by the temporal production of the photographs. Rather, he chose images from a wider repertoire that encompasses all his field visits, conceiving of their potential as a visual element for the time-compressed journey he constructed in the book.

Carvalho's two-page plan shows an initial idea of defining 61 illustrations throughout the narrative. Three of them are associated with different kinds of indecisions. The first includes references to two images: between one of a shepherd with milking vessels (see Figure 2), or of Batupo, one of his closest Ovakuvale collaborators, with a milking vessel. The second is about choosing between an image of an elao, the place for the sacred fire in a permanent fenced settlement, or of the inside of an onganda, the permanent settlement. The third regards the conditions of the journey, either by showing an image with his jeep far on the horizon or one where Paulino, his research assistant, is faraway near the jeep, with his back to the camera. Handwritten numeration linking images in the proofs to the plan's descriptive orientations provides some field context for the printed intermediary repertoire, which reunites thematic repetitions for him to choose from for his final selection, and enables us to pursue two meandering processes, one related to Carvalho's field and the other to his publishing choice. 


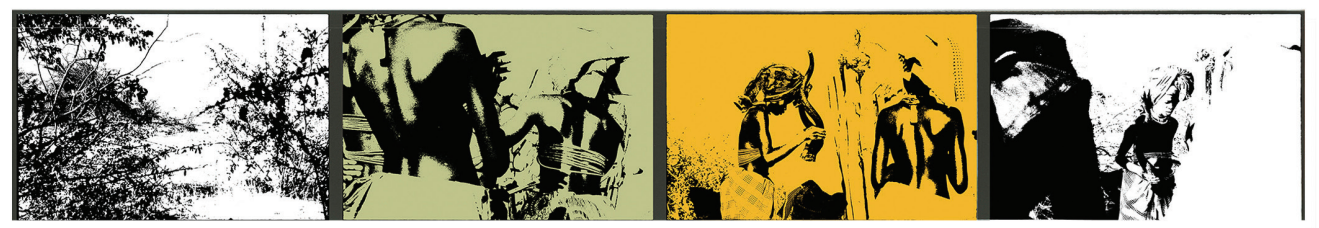

\begin{tabular}{|l|l|l|l|}
$\begin{array}{l}\text { field } \\
\text { photography }\end{array}$ & $\begin{array}{l}\text { used as a test } \\
\text { for the book } \\
\text { VLVP }\end{array}$ & $\begin{array}{l}\text { photo } \\
\text { published in } \\
\text { VLVP }\end{array}$ & $\begin{array}{l}\text { field } \\
\text { photography }\end{array}$ \\
\hline
\end{tabular}

VLVP: CARVALHO, Rui Duarte de Carvalho. Vou Lá Visitar Pastores. Lisboa: Cotovia, 1999.

Figure 3: A selective venture. Display tracing Carvalho's selection process, generated by looking at his photographic production, the intermediate proofs and the book. This filmstrip from roll 17w/1994K has signalled archived photograph, chosen proof and final selected image. Both coloured images depict women putting an old Oholongo horn on the thifa (showcase at the ceremonial altar) as a payoff to a spirit demanding this animal in particular to leave the possessed woman in the house.

The graphical transformation of field images in Vou Lá contrasts with some of the subsequent usages of his Ovakuvale field images for events in which Carvalho collaborated. Comprising a series of events of an ephemeral nature, I start by discussing the adaptation of the book into a theatre play.

\section{Principles for Converting a Book into a Theatre Play}

A few years after Vou Lá Visitar Pastores came out, Carvalho welcomed the idea of seeing it adapted into a homonymous theatre play - an idea emerging in 2003 from a cultural programmer based in Lisbon who was interested in showing a wide range of contemporary creations from various geographies. Carvalho worked closely with the invited playwright to adapt his book into a theatre play. ${ }^{31}$

Compressing further the literary journey that resulted from Carvalho's long-term fieldwork among the Ovakuvale, the play kept the book's structure. To create the atmosphere for the text, the play production took advantage of the full range of resources Carvalho had generated in the field. It used Carvalho's sound and video field recordings, and also his photography and drawings, to support a monologue shaped as a kind of lecture on the Ovakuvale - which the book's narrative device of spoken letters facilitated. Being aptly described as a lecture-theatre, it brought the Ovakuvale

31 The then artistic director of a state cultural institution for more than a decade, António Pinto Ribeiro (n. 1956) invited an actor to make a monologue based on the book, who in turn partnered with a playwright, a scenic director, and a sound designer. 

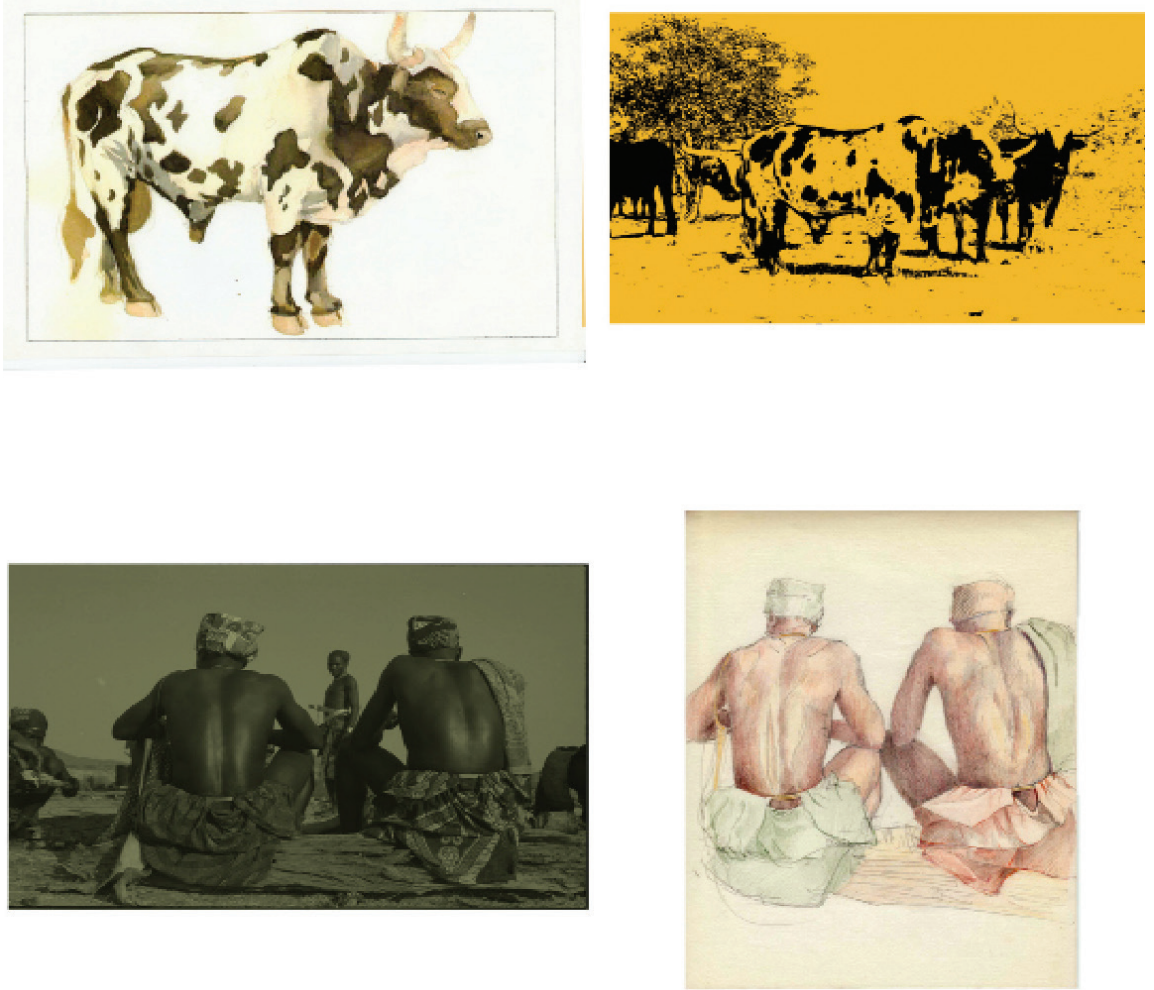

Figure 4: Theatrical Juxtapositions. Watercolour of a dumenthu, a castrated bull, used for the promotion of the play at Culturgest, in Lisbon 2004, based on a frame from R17w/1994K which had appeared in the book Vou Lá (p. 271). Below is a B\&W version of a colour field photograph from R37w/1995, taken during a slaughtering and meat consumption meeting, used in a postcard announcing a later staging of the play, and Carvalho's drawing inspired by the same image.

lifeworld to the stage with the support of a widescreen shifting between the real-time slideshow controlled by the actor, and the display of preselected audiovisual and field images. Not constrained by the B\&W publishing limits, it appeared more compelling to show the field images with a smoother filter to project the Ovakuvale and their lifeworld into the minds of the attending audience.

About two years after its premiere, the playwright Rui Guilherme Lopes reflected that the play might have turned out to be too much of a lecture for theatre fans and too much of a play for anthropologists. ${ }^{32}$ It might, however, also work the other way around: providing an insightful lesson on both anthropology and theatre. Sharing Carvalho's intention with the book as an experiment in ethnography, this opportunity can also be seen as an experiment in both ethnography and theatre. The theatre play was also important for Carvalho's wider public recognition, promoting the 
broader dissemination of his Ovakuvale ethnography to a wider general audience in ways that the book could only achieve in limited ways. Premiering in Lisbon in 2004, the play was presented in several Portuguese cities in the following years and also circulated, for instance, in Brazil and Mozambique (Figure 4). Indeed, Lopes mentions his hope that the play would create a desire in its audience to read the book. ${ }^{33}$

The theatre play was the first of a few of Carvalho's collaborative ventures to present his Ovakuvale ethnography, giving him the opportunity to see how those unfamiliar with his work and subject engaged with his related ethnographic undertaking. Below, I highlight his involvement in the curatorship of two exhibitions on his work: Sem Rede/Without Net, curated by Nuno Porto, 2005, Coimbra; and Deime Portanto a um Exaustivo Labor/So I Carried out an Exhaustive Labour, curated by José Fernandes Dias, 2008, Lisbon. Taking place in Portugal, the play was part of the accompanying programme in both instances. Furthermore, fellow anthropologists curated both.

\section{Inverted Mirrors:}

\section{The Exhibitions' Curatorial Uses of the Ovakuvale Field Photographs}

Neither of the transient exhibitions was a photography exhibition per se, yet in both the field photographs had a substantial role, appearing again as relevant devices for the public diffusion of Carvalho's Ovakuvale ethnography. The exhibitions included different displays of prints in the currently common consumer size (10x15), yet the 2008 one also included another distinctive display device. Differences apart, they shared some commonalities, such as using Carvalho's writing for their titles. Both exhibitions also developed devices that introduced him and his work before letting the audience encounter the images, attempting to provide the visitor with a prior interpretative context to the lifeworld of the portrayed Ovakuvale.

Separated in time by a couple of years, the exhibitions arose from different institutional arrangements, the former taking place at a university museum, the latter at a cultural centre, in different Portuguese cities. Nuno Porto reflects how the same materials can be used to provide different meanings according to the contexts in which they are displayed. ${ }^{34}$ Such reflection helps to situate some inverted mirroring features in these exhibitions, both of which counted on Carvalho's full cooperation. For instance, the 2005 exhibition started with the contemporary context of Carvalho's ethnographic work, and its narrative led to Carvalho's previous film work in the same region. The 2008 exhibition followed a more temporally progressive narrative - first situating several of Carvalho's prior works that then opened on to the Ovakuvale venture. Strictly speaking, however, the visitors could choose between two parallel displays.

33 Ibid.

34 N. Porto, 'From Exhibiting to Installing Ethnography Experiments at the Museum of Anthropology of the University of Coimbra, Portugal, 1999-2005', in S. Macdonald and P. Basu (eds), Exhibition Experiments (John Wiley \& Sons, 2008), 175-96. 
Both curators being anthropologists and university teachers, the differing display approaches might reflect their respective specialisations and interests. For about a decade, Porto had explored the field of museum anthropology in Coimbra, promoting a series of exhibitions combining teaching and museum practice. At the faculty of fine arts in Lisbon, Dias had been concerned with the anthropology of art through a curating-based practice, specialising in African art. Both exhibitions resulted from the varying aims and means at their disposal, and, importantly, their targeted audiences. Porto has discussed how his curatorial approach at the university museum was always less concerned with achieving a broader audience than with finding conceptual devices that dialogued with the discipline's ongoing debates on museum exhibitions. ${ }^{35}$ The 2008 curatorship by Dias fits into his curatorial trajectory related to contemporary Africa, yet the original invitation arose from the programmer of the well-visited cultural centre who had a passion for literature and was very impressed by Carvalho's literary work. Similar to the idea guiding the theatre play some years before, the 2008 exhibition aimed to make Carvalho's work reach a broader audience. The 2008 exhibition succeeded in travelling to Angola the year after, with the accompanying colloquium gathering a broader set of Angolan specialists to discuss Carvalho's work than the Lisbon version. Yet the overall programme there lacked the film screenings or the theatre play that had taken place in Lisbon - events with the potential of reaching wider audiences.

The two exhibitions have an inverted presence in Carvalho's archive: the great quantity of preproduction materials related to the 2008 exhibition contrasts with the existing released materials created for the 2005 exhibition. Envelopes named with the different sections of the 2008 exhibition keep the original materials used, some with sets for glass-case display, others with the preproduction materials for composing long scrolls for display. Showing Carvalho's role in selecting the images and texts presented in its various sections, they combine sets of prints and pieces of paper with his handwritten notes on typed text. The materials related to the 2005 exhibition only consist of copies of a catalogue in braille and flyers that were produced, and it is thus most useful that the curator Porto has discussed it in print.

Porto highlights the major role the Ovakuvale field photographs played as the central device to promote the sense of being an ethnographic installation rather than an exhibition. ${ }^{36}$ After a written and spoken introduction by the author, the photographs appeared along a wall in plastic pocket sheets as if an archive was on display. Constituting a corridor with glimpses of Carvalho's field experience caught by his photo camera, the images depicted the Ovakuvale everyday life and special occasions. On the 2008 journal exhibition, Porto mentions that Carvalho's organised photographic archive had impressed him to such an extent that he decided to use it as

35 Ibid.

36 Ibid. This event was part of a cultural week by the University of Coimbra dedicated to the Lusophone world, including a series of activities related to Carvalho's work. Carvalho had been a guest professor at the anthropology department of the university in the 2000-1 academic year. 
a display device. ${ }^{37}$ The thematically organised photographs have, however, vanished from Carvalho's archival assemblage - in contrast with Isaac Schapera who, while not publishing many of his field photographs during his lifetime, had categorised and captioned them carefully. ${ }^{38}$ Cross-referencing with Carvalho's 2008 exhibition preproduction materials, we catch glimpses of what those categories might have been.

While the 2005 exhibition dealt with the idea of transposing a whole photographic archive produced through fieldwork, a substantial section of the 2008 exhibition was its display of long scrolls of tracing paper on the wall, intertwining selected images with sentences from some of Carvalho's books at the time. The selections combined image and text in bigger size displays, involving a sophisticated process of intervention in their arrangement to invoke Carvalho's work. Meant as a wider retrospective of a multifaceted author, the scrolls included as Ovakuvale-related themes shepherds, women, landscapes, cattle, meat, cemeteries, rocks. In other words, the central themes that had already emerged in the 1999 Vou Lá publication: the semi-arid landscape, a gendered approach, and core social activities such as cattle slaughtering and meat consumption.
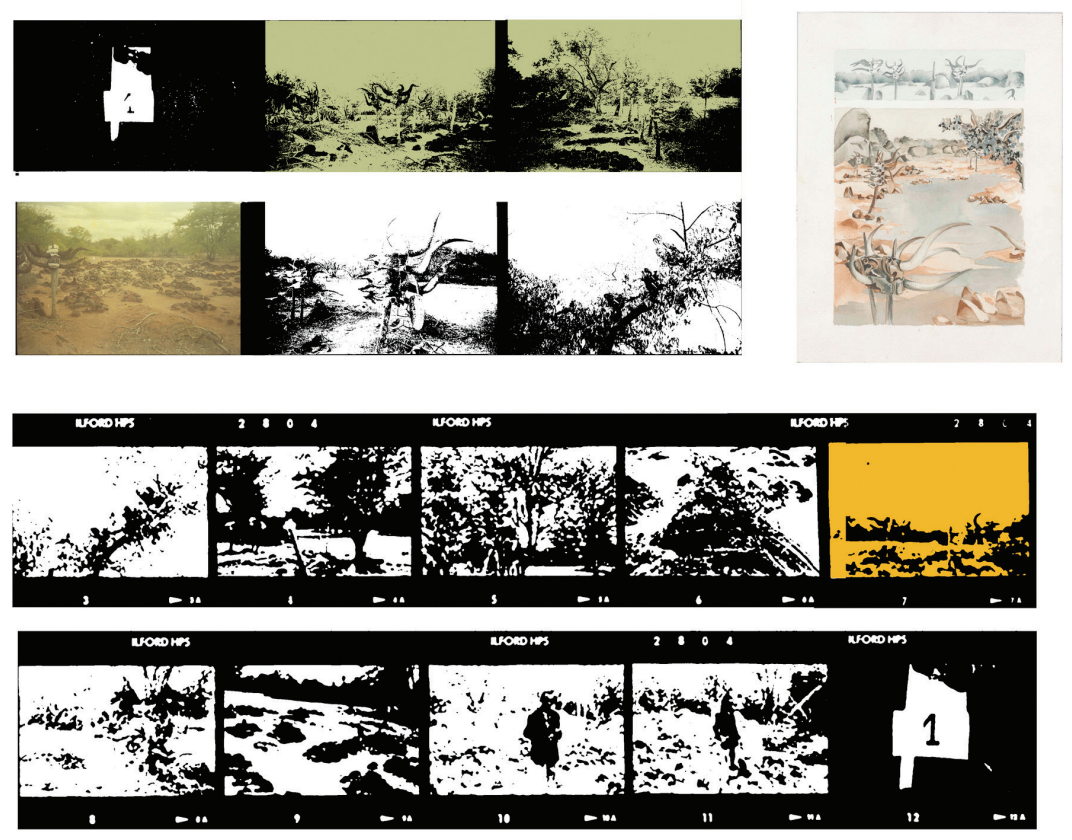

Figure 5: A handful of layers. Sequences made from different cameras (top, r7w colour; bottom r8w, B\&W) during Carvalho's visit to a cemetery on his 1993 trip, juxtaposed with later usages: archive (white filter), 1999 intermediate proofs (green filter), 1999 book (yellow filter), 2008 exhibition display (unfiltered) and a drawing depicting what I call a 'leap of imagination' His fieldnotes show that the visit deeply impressed him; the 1999 outline indicates that Bahiputa, one of the Ovakuvale collaborators who Carvalho met first in his youth, accompanied him. 
I now briefly discuss the 'leap of imagination' found in some of Carvalho's drawings and watercolours based on a few of his Ovakuvale field images.

\section{Layered Images and Displays: Field Photography and Drawing}

If Carvalho's Ovakuvale field photographs can be generically dated from his main fieldwork period between 1992 and 1997, his drawings and watercolours based on them are more complicated to place by approximation. Carvalho's experiment with refashioning field photographs appears as another way for him to think through his field experience after some time, yet there appear to be various moments for this practice. In this technique he also explored three main topics: Luanda from his long-term house and also from a downtown hotel; the southern desert landscape and its stones and wooden remains; and the Ovakuvale. In the last years of his life he invested time in practising watercolours, yet the handwritten date on one of his Ovakuvale-related watercolours shows an earlier engagement, one that appears to share the inverse temporal nature of his experiment with illustrating his 1999 book. ${ }^{39}$ Showing an imaginative leap from the photograph that inspired it, the drawing, titled 'The night comes from the left', which transmutes the time of the day depicted in the photograph, was made eight months after his first trip, and three months before the following trip - that is, at the beginning of his long-term fieldwork.
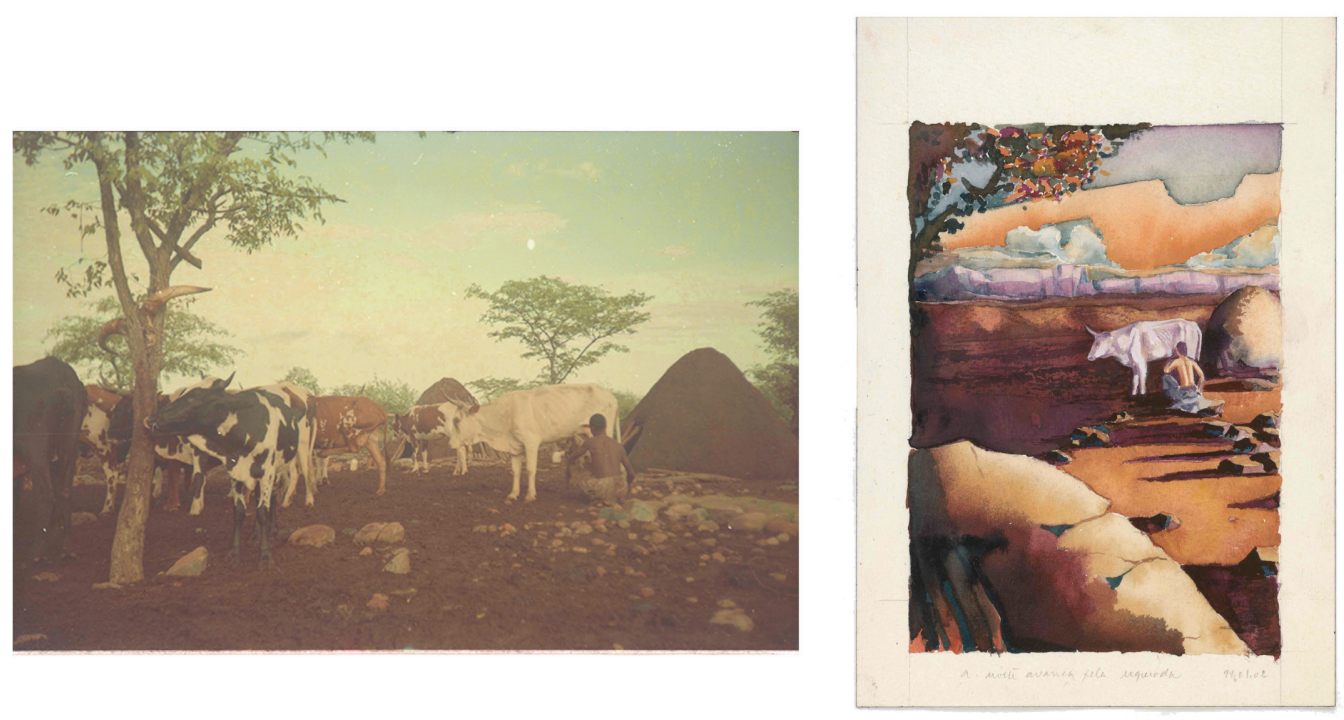

Figure 6: An imaginative leap I. Unpublished first frame of the roll 15w/1993 and related watercolour. This roll depicts cattle in the early morning waiting for the milking to finish and to be released from their kraal, at a temporary site. Carvalho painted watercolours inspired by many of the frames that follow it, depicting the cattle waiting.

39 The image used for the cover of Aviso à Navegação (Luanda: INALD, 1997), a book that reunites essays on the Ovakuvale, is also a watercolour, kept in Carvalho's personal archive, yet the frame that might have inspired him appears to be missing. 
For Carvalho, drawings and watercolours were a visual practice that not only linked him back to his Ovakuvale experience, but also enabled him to think for resonances. He often used drawing and watercolours to direct his look, but he also took a few imaginative leaps. Morton proposes the term 'graphicalization of description' to understand how the museum curator Henry Balfour (1863-1939) related to his field photography and drawing. ${ }^{40}$ Carvalho's practice to draw artistically from what is photographically inscribed responds better to the notion of 'education of attention, ${ }^{41}$ a process that involves dynamic 'labours of maturation' and a capacity to experiment with different ways to express his fieldwork experience, often grounded in his field photography.
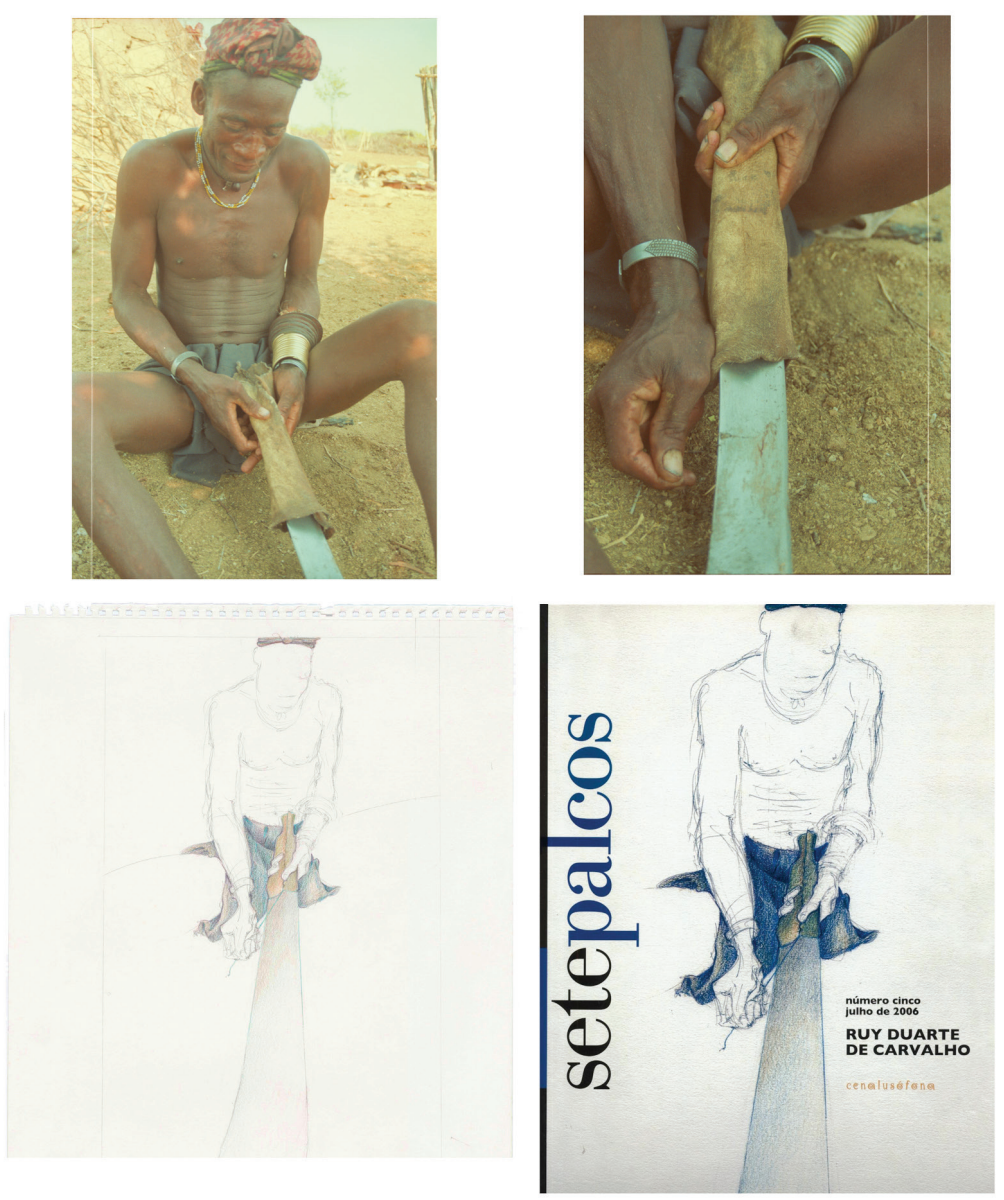

Figure 7: An imaginative leap II. Two frames from R26w/1994E, juxtaposed with an undated drawing and the cover of SetePalcos (2006), dedicated to his work. Carvalho had photographed other similar situations in previous trips; this drawing appears inspired by both frames rather than emulating a single image.

41 T. Ingold, 'From the Transmission of Representation to the Education of Attention', in H. Whitehouse (ed), The Debated Mind: Evolutionary Psychology versus Ethnography (Oxford: Berg, 2001), 113-53. 

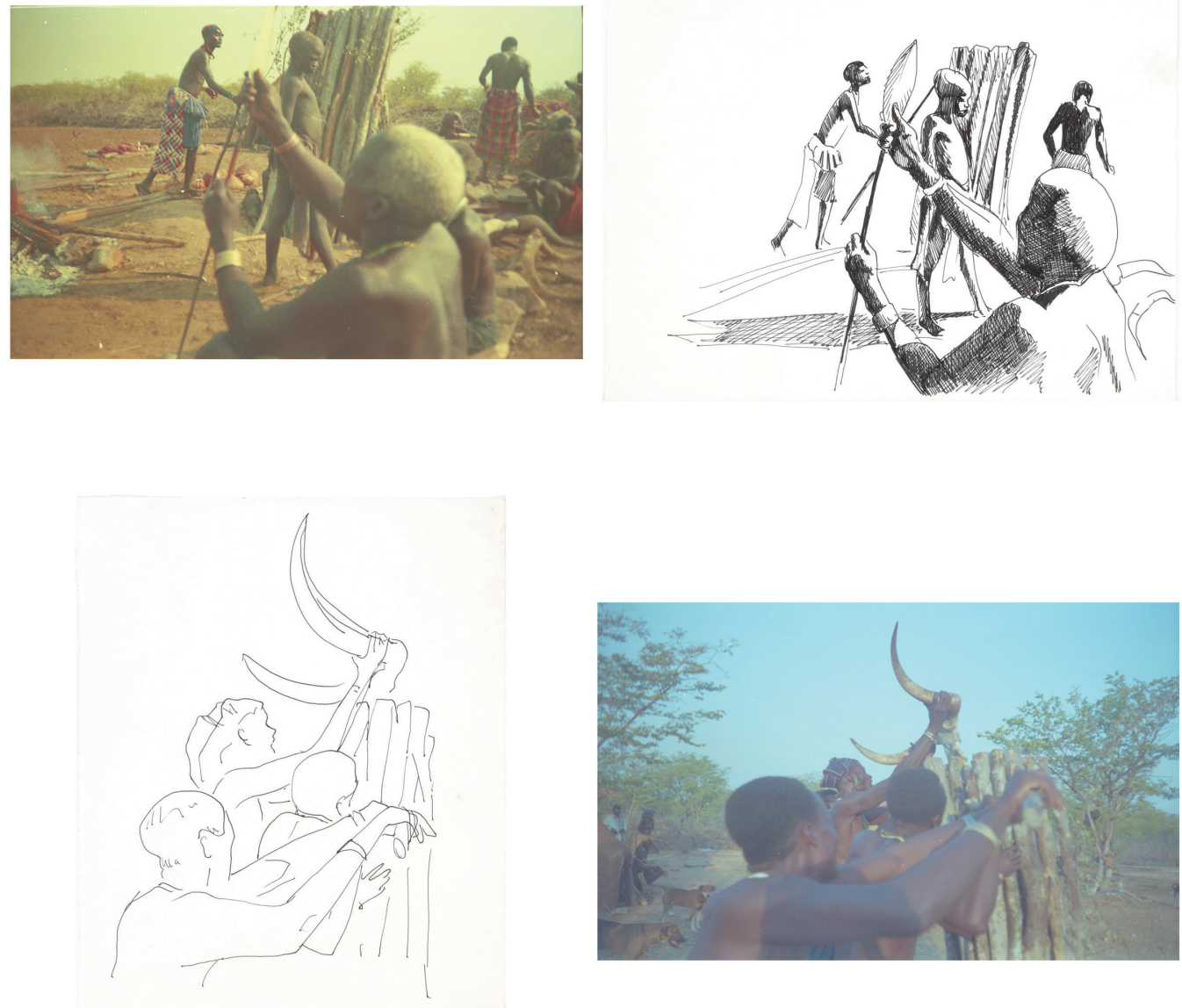

Figure 8: An imaginative leap III. Frame from r30w/1994G and r32w/1994O, juxtaposed with Carvalho's undated ink sketches.

There are two printed publications in which Carvalho provided combined images of his field photographs, and drawings or watercolours based on the former: for the special issue emerging from the cultural week at the University of Coimbra that included the 2005 exhibition, and for the 2008 exhibition journal. ${ }^{42}$ Both richly illustrated publications combine texts from Carvalho and several researchers who discuss his diverse cultural production, engaging with his work on literature, anthropology, and cinema. Depicting all kinds of engagements of Carvalho with his field images, these publications enrich the understanding of his openness to visual experiments. It is a pity that the assemblage of Carvalho's personal archive only has B\&W copies of the 2006 issue, which is currently sold out.

42 'Ruy Duarte de Carvalho', Setepalcos 5 (Coimbra: Cena Lusófona, 2006) also includes a couple of Carvalho's earlier film stills and six photographs by Rute Magalhães, made during the shooting - all appearing also at the 2005 exhibition - and an illustration related to the theatre play commissioned by the University of Coimbra to a local theatre group, which also edited the volume. The 2008 exhibition journal includes images from later trips to southern Angolan and northern Namibia. 
To close, I present a couple of Carvalho's other creations, two different leaps of imagination regarding his Ovakuvale field photographs (see Figure 8). Showing images that until now appear to have remained in his personal archive, they taught me a lesson in the 'education of attention' necessary to engage with Carvalho's kaleidoscopic work and his Ovakuvale photography. The first time I looked at these drawings, I connected them to other experiences from the period around or before his film phase, close to Angola's independence. Only after attentively engaging with Carvalho's Ovakuvale photographs did I realise my mistake.

\section{Conclusion}

This article engaged with the afterlives of field images by a late ethnographer, Ruy Duarte de Carvalho, addressing the interplay between their archival existence and both ephemeral and enduring usages during his lifetime. Emerging from a documentation practice conducted over his extensive fieldwork in the 1990s, the various lifetime uses of his Ovakuvale field images show Carvalho's openness to experimenting with the visual as a valuable dimension to communicate his ethnographic insights to various kinds of audiences. His 1990s field photography practice among the Ovakuvale was followed by distinctive uses for dissemination of his ethnographic work regarding these transhumant shepherds in southern Angola: an experimental ethnographic monograph embodying a selection of field images in high contrast (1999), two exhibitions he co-curated in his lifetime $(2005,2008)$, a theatre play (2004) and a magazine issue (2006). I proposed an understanding of Carvalho's field production to highlight guiding principles in these later uses of his field images.

To recover an ethnographer's lifetime usages, I engaged with the currently crippled version of his personal archive that mediates his field photography practice in its various occurrences. Demonstrating Carvalho's continuous openness to thinking through his field documentation images in relation to his multiple and differentiated usages of them, brought a set of questions about contemporary usages of field photography in anthropology, namely diverse shapes of collaborations and their interconnections with academic and broader audiences for ethnography.

Taking Carvalho's practice as ways in which his field methods and experience and public dissemination relate to each other, revealed the particular imagery Carvalho assumed for his Ovakuvale ethnography. Analysing the other lives of his field images to think through his ethnographic approach to the Ovakuvale, I was able to progressively establish what characterises his field photographic style. Following different occasions and initiatives shaped an understanding of the ways in which Carvalho looked at his field images as continually providing enriching visual features to his Ovakuvale ethnography, giving or mediating their other lives.

I studied Carvalho's Ovakuvale field documentation photography in combination with a wide range of his lifetime usages, relating archived photographs to varying usages that have made them circulate in and out of their archive for ethnographic purposes. Finding Carvalho's archive full of both illuminating and deceiving clues regarding a temporal dimension, to benefit from the former and overcome the 
latter, I worked by approximation. To look at Carvalho's photography production, I combined readings of his typewritten field diaries as a major resource to retrace the circumstances of his field production, which enabled me to draw an account based on tentative and progressive reordering of the materials. To retrace his later usages, I looked at physical components in the archive, namely a set of intermediate plans for his first illustrated book and the existing materials of the exhibitions with their public traces.

Rather than following a linear temporal discussion of the later occurrences in which Carvalho's Ovakuvale images have been activated, I engaged with changeable dimensions among them, and discussed the varying processes that converged in their final displays - in this way I hope to have highlighted both Carvalho's evolving understanding of his own work, and the context in which they took place. Beyond the progressive occurrence of permanent and ephemeral presentations, his occasional watercolour practice based on his field images developed at different moments, and not only brought closure to the varying temporalities embedded in both his work and his personal archive, but also a continuous process of maturation. The varying temporalities - not only the moments in time in which the discussed projects took place, but also their various timings - opened to ways in which Carvalho's engagement with his Ovakuvale images is grounded in a gradual and undetermined education of his attention. Lastly, I have attempted to provide visual displays that depict Carvalho's varying lifetime usages of his Ovakuvale images, guided by the idea of revealing both the impurities time has added to them and glimpses of the Ovakuvale lifeworld. 